Volume 4 No 2 Maret 2019

p-ISSN : 2460-8750 e-ISSN : 2615-1731

http://dx.doi.org/10.26858/talenta.v4i2.8242

\title{
SELF COMPASSION VERSUS SELF ESTEEM TERHADAP PEMBENTUKAN SELF-CONCEPT REMAJA: MANA YANG LEBIH BAIK?
}

\author{
Andhika Alexander Repi \\ ${ }^{1}$ Fakultas Psikologi, Universitas Katolik Widya Mandala Surabaya. Indonesia \\ Email: andhika@ukwms.ac.id
}

(C2019 -JPT Fakultas Psikologi Universitas Negeri Makassar. Ini adalah artikel dengan

akses terbuka di bawah licenci CC BY-NC-4.0 (https://creativecommons.org/licenses/by-nc/4.0/ ).

\begin{abstract}
Abstrack. Adolescent need to establish a positive self-concept in order to complete their development task. Various psychological variables contribute to adolescent self-concept including self-esteem. However, self-esteem only makes the adolescents filled with the need to always try to be above others or beyond the existing social standards. This variable will force adolescents to maintain a high level of self-esteem or at least above the average of environmental evaluation. Selfcompassion is present as a more positive variable in the effort to form adolescent self-concept. Selfcompassion does not exclude adolescent self-evaluation. Self-compassion helps adolescents to give an understanding of being good to themselves (self-kindness), shaping the idea that the situation they are experiencing now can also be experienced by others (common humanity), as well as full awareness of doing a mindfulness, then they will able to form a more positive self-concept. Adolescents need to develop self-compassion rather than focusing on self-esteem in the effort to form self-concept
\end{abstract}

Keywords : self concept; self compassion; self esteem; adolescent; personal development

\begin{abstract}
Abstrak. Remaja perlu membentuk self-concept yang positif dalam proses pencarian jati dirinya. Berbagai variabel psikologi turut membentuk self-concept remaja termasuk self-esteem. Akan tetapi, self-esteem hanya membuat diri para remaja diliputi kebutuhan untuk selalu berusaha berada di atas orang lain atau melebihi standart sosial yang ada. Variabel ini akan memaksa para remaja mempertahankan tingkat self-esteem yang tinggi atau setidaknya di atas rata-rata dari penilaian lingkungan. Self-compassion hadir sebagai variabel yang lebih positif dalam usaha membentuk selfconcept remaja. Self-compassion tidak meniadakan evaluasi remaja dari diri maupun lingkungan. Self-compassion membantu remaja untuk memberikan pemahaman perlu bersikap baik terhadap dirinya sendiri (self-kindness), membentuk pemikiran bahwa situasi yang dialaminya sekarang bisa juga dialami oleh orang lain (common humanity), serta secara kesadaran penuh melakukan suatu tindakan (mindfulness), maka ia mampu membentuk self-concept yang lebih positif. Remaja perlu mengembangkan self-compassion daripada terfokus pada self-esteem dalam usaha membentuk selfconcept.
\end{abstract}

Kata Kunci: self concept, self compassion, self esteem, remaja, pengembangan personal

\section{PENDAHULUAN}

Jumlah penduduk Indonesia yang

dirilis dari Situs Worldometers (2017) mencapai angka lebih dari 263 juta jiwa.
Dalam laporan Proyeksi Penduduk Indonesia yang dikeluarkan oleh Badan Perencanaan Pembangunan Nasional dan 
Badan Pusat Statistik (2013) menunjukkan bahwa pada tahun 2017, 17\% penduduk Indonesia berada dalam rentang usia 10-20 tahun. Proyeksi angka tersebut mengalami peningkatan pada tahun 2018 menjadi sekitar $18 \%$ dari penduduk Indonesia atau sekitar 45 juta jiwa. Angka pertumbuhan penduduk ini pun menjadi modal bagi Indonesia untuk mendapatkan bonus demografi pada tahun 2030 (Presiden Joko Widodo, dalam Kompas, 2017). Artinya, Indonesia akan mendapatkan angkatan kerja produktif yang sangat banyak, bahkan menjadi terbanyak di dunia. Sebagai upaya untuk mempersiapkan bonus demografi tersebut, para angkatan usia ini pun perlu mendapatkan peningkatan kualitas.

Remaja merupakan salah satu tahapan seseorang yang berada di antara fase anak dan dewasa. Erikson (dalam Santrock, 2007) dalam teorinya mengenai Tahap Perkembangan Psikososial menjelaskan bahwa masa remaja merupakan salah satu tahap perkembangan manusia dengan rentang usia 10-20 tahun. Erikson menyebutnya sebagai tahap identity vs identity confusion. Para remaja dihadapkan pada tantangan untuk menemukan siapa dirinya, bagaimana ia kedepannya, serta akan kemana arah hidupnya berlabuh. Mereka pun akan dihadapkan pada peran-peran baru dan mulai dihadapkan pada hal seperti pekerjaan dan romantika (Santrock, 2007).
Ia pun akan dihadapkan pada sejumlah tugas perkembangan yang berkaitan dengan diri sendiri serta lingkungan sosial yang dihadapinya (Agustiani, 2009).

Semua perubahan dan dinamika yang dialami oleh para remaja menuntut dirinya untuk melakukan adaptasi di dalam dirinya. Remaja perlu menerima perubahan yang terjadi sebagai bagian yang alami dari suatu proses perkembangan. Pembentuk sense of self yang baru tentang siapa dirinya dalam rangka mempersiapkan diri menghadapi masa dewasa adalah hal krusial bagi remaja (Ybrandt \& Armelius, 2003; Agustiani, 2009).

Konsep diri merupakan konstrak variabel yang multi-dimensional dan mengacu pada persepsi individu mengenai dirinya sendiri. Konsep diri adalah bagaimana individu melihat pribadinya secara utuh baik secara fisik, psikologis, intelektual, sosial, dan spiritual atau biasa disebut sebagai pemahaman biopsikososiospiritual. Konsep diri juga berisikan persepsinya mengenai sifat serta potensi yang dimilikinya, nilai yang dianut, tujuan, harapan, serta keinginannya. Konsep diri inilah yang kemudian akan membentuk identitas bagi diri seorang individu khususnya para remaja (Santrock, 2007, Saraswatia, Zulpahiyana, Arifah, 2015).

Konsep diri merupakan suatu pengetahuan tentang diri sendiri yang bisa 
memengaruhi perilaku dan tindakan individu. Pembentukan konsep diri melalui dua cara, yaitu bagaimana individu menilai dirinya sendiri, dan bagaimana orang lain menilai dirinya. Pandangan individu mengenai dirinya dipengaruhi oleh bagaimana ia mengartikan pandangan orang lain tentang dirinya. Intinya adalah konsep diri adalah evaluasi diri seorang remaja tentang dirinya sendiri, dan refleksi dari cara pandang orang lain terhadap dirinya (Saraswatia, Zulpahiyana, Arifah, 2015; Wankahade, 2016)

Pembentukan konsep dari dari seorang remaja berasal dari proses penilaiannya terhadap diri sendiri dan dari lingkungan sekitarnya. Kejelasan konsep diri tersebut pun memfasilitasi terbentuknya identitas yang lebih komperhensif dari seorang remaja (Saraswatia, Zulpahiyana, \& Arifah, 2015; Augestad, 2017)

Namun, konsep diri dari pembentukan self-esteem belum tentu menghasilkan identitas yang optimal bagi diri remaja. Mengapa? Self-esteem adalah penilaian individu tentang dirinya yang "hanya" muncul ketika individu membandingkan dirinya dengan suatu tolok ukur tertentu, entah situasi ataupun orang lain. Sehingga, hal ini mengaburkan esensi dari pembentukan self-concept, yaitu konsep diri pada seorang individu terbentuk melalui penilaian orang lain terhadap diri individu, dan penilaian individu terhadap dirinya sendiri. Individu perlu mengalami dirinya secara sadar sebelum membentuk konsep dirinya (Wankhade, 2016).

Remaja harus lebih memfokuskan dan mengubah cara pandang bahwa kritikan adalah hal yang membantunya bukan untuk menjatuhkannya (Duffy \& Atwater, 2005). Hanya saja, Self-Esteem adalah variabel psikologis dari diri individu yang rentan terhadap kritikan.

Pada umumnya, orang yang mengalami kritikan akan merasa terhina, terabaikan ataupun merasa marah. Perasaan tidak berharga, tidak berdaya, terkalahkan dan lemah akan muncul dan melingkupi dirinya. Bahkan, lingkungan yang menganggap dirinya sebagai "orang yang biasa saja" pun mempengaruhi penurunan self-esteem. Padahal, situasi tersebut belum tentu sesuai dengan fakta (Neff \& Vonk, 2009). Inilah peran penting dari konsep self-compassion yang siap "menjaga" diri individu. Self-compassion tidak menjamin individu terhindar dari kritikan ataupun menuntut agar tidak mengevaluasi pendapat orang lain tersebut. Self-compassion akan lebih pada membentuk emosi positif sehingga, individu tidak jatuh jatuh dalam keterpurukan akibat berbagai respon negatif lingkungan terhadap dirinya (Neff, 2003b; Leary, Tate, Adams, Allen \& Hancock, 2007; Neff, 2011; Breines \& Chen, 2012; Persinger, 2012; Marshall, Parker, Ciarrochi, Sahdra, Jackson, \& Heaven, 
2014; Marshal, Parker, Ciarrochi, Sahdra, Jackson \& Heaven, 2015; Kamalisanasab \& Mohammadkhani, 2017).

Kharina (2012) menyatakan bahwa semua manusia selalu berusaha menjadi yang terbaik agar mencapai self-esteem yang tinggi. Keinginan untuk mempertahankan tingginya self-esteem dari dirinya membuat individu selalu memandang diri lebih baik dari yang sebenarnya. Cara bagaimana kita melihat di dalam diri kita sendiri adalah lebih penting dan lebih menentukan perilaku individu ke depannya daripada self-esteem itu sendiri (Duffy \& Atwater, 2005). Inilah yang ditawarkan oleh Self-compassion. Selfcompassion akan membebaskan diri dari berbagai pandangan lingkungan sosial terhadap diri individu. Variabel ini pun membantu individu untuk menilai dirinya dengan menggunakan welas asih atau compassion. Self-compassion pun ditemukan memiliki korelasi kuat dengan pembentukan karakteristik positif dari diri individu (Neff, 2003; Leary, et al, 2007; Muris, et al, 2015; Marshall, et al, 2014; Marshall, et al, 2015; Karakasidou \& Stalikas, 2017). Inilah yang kemudian membuat pengembangan self-compassion menjadi penting bagi remaja.

\section{METODE}

Penelitian ini merupakan kajian pustaka dan pendalaman konsep teoritis terhadap variabel self-compassion, self esteem, dan self concept pada remaja.

\section{HASIL DAN PEMBAHASAN}

Mengapa Remaja perlu membentuk selfconcept?

Individu yang memasuki tahap perkembangan remaja akan mengalami berbagai perubahan terhadap dirinya. Peran keluarga yang selama ini dominan dalam memengaruhi perkembangan dirinya pun mulai pudar tergantikan oleh peran lingkungan pergaulannya (Laible, Carlo, Marcela, 2000; Nickersen \& Nagle, 2005; Santrock, 2007). Dinamika kehidupan yang terjadi pada diri remaja akan membuatnya berusaha mencari jati dirinya, tentang siapa dirinya, dan bagaimana dia kedepannya. Erikson menyebut fase ini sebagai fase pencarian vs kebingungan identitas (Erikson, 1968). Bahkan, Hall (dalam Herlina, 2013) menyebut bahwa remaja memasuki masa yang penuh topan dan badai. Kecemasan, kekhawatiran, ketakutan merasa inferior adalah kondisi yang "normal" yang akan dihadapi oleh para remaja. Namun, hal tersebut harus bisa dilalui oleh para remaja. Mereka harus berusaha sekeras mungkin untuk menemukan jawaban siapa diri mereka, bagaimana peran mereka di keluarga maupun di masyarakat. Mereka harus menemukan identitas dirinya. Namun, bukan hal yang mudah mengingat di dalam 
pencapaiannya, remaja akan dihadapkan pada berbagai perkembangan lainnya, seperti fisik, mental, emosional dan sosial (Erikson, 1968; Santrock, 2007)

Identitas yang "dicari" oleh para remaja terekonstruksi oleh konsep diri atau self-concept yang dibangun oleh para remaja. Self-concept yang merupakan hasil persepsi dan evaluasi individu terhadap bagian dari dirinya (Palacios, Echaniz, Fernandez, \& Barron, 2015; Saraswatia, et al, 2015; Veiga \& Leite, 2015; Martins \& Neto, 2016; Wankhade, 2016). Konsep diri menjadi suatu hal yang penting bagi remaja dan berperan dalam hidupnya. Di dalamnya terdapat kesadaran penuh bahwa ia menyadari dan mengakui tentang identitasnya, jenis kelaminnya, apa tujuannya, bagaimana penilaiannya terhadap peran di masyarakat, bagaimana identitas religious dan pendidikan, serta bagaimana ia memandang kepribadiannya (Santrock, 2007)

Self-concept dipengaruhi oleh penilaian dan interaksinya dengan orang lain. Seseorang harus mendapatkan reaksi dari orang lain untuk meyakinkannya bahwa ia berada dalam kondisi tersebut. Seorang remaja putri menilai dirinya cantik hanya jika ada tanggapan atau reaksi dari orang lain yang menunjukkan bahwa ia cantik. Begitu pula dengan remaja pria (Agustiani, 2009). Self of sense sebagai bagian dari self-concept pun dipengaruhi oleh sosial budaya yang kemudian berpengaruh pada peran dan hubungan individu di lingkungan sosialnya (Duffy \& Atwater, 2005).

Remaja perlu memiliki pengetahuan yang utuh dan menyeluruh mengenai konsep dirinya. Jika mereka mampu membentuk konsep diri yang positif, maka dengan mudah para remaja akan menemukan jati dirinya. Jati dirinya ini yang akan membuatnya lebih berkembang baik secara fisik, psikis, dan sosial. Namun sebaliknya, jika konsep diri yang negatif terbentuk dalam diri para remaja, maka remaja rentan berperilaku maladaptif, seperti berkelahi, berbohong, kesalahan menggunakan narkoba, melakukan kekerasan dan sebagainya (Erikson, 1968; Santrock, 2007; Agustiani, 2009Saraswatia, et al, 2015; Veiga \& Leite, 2015; Martins \& Neto, 2016; Wankhade, 2016).

Dengan demikian, remaja perlu membentuk self-concept yang positif sehingga mereka mampu melewati masamasa sulit ini. Pembentukan self-concept yang positif akan menstimulasi remaja lebih siap untuk melanjutkan ke tahap perkembangan berikutnya, yaitu masa dewasa.

Self-concept dibentuk dari self-esteem dan self-compassion, mana yang lebih baik? Self-Esteem adalah variabel psikologis yang mampu membentuk konsep 
diri bagi individu termasuk remaja. Begitu juga dengan self-compassion yang bisa membantu individu untuk lebih bermakna dalam hidupnya melalui pembentukan konsep diri yang jelas. Di dalam tahap perkembangannya, seorang remaja perlu membentuk self-concept yang jelas. Kejelasan tersebut akan berkaitan dengan pembentukan identitas sebagai indikator keberhasilan tugas perkembangannya (Erikson, 1968; Santrock, 2007). Tetapi, konsep diri yang jelas belum menjamin terbentuknya identitas yang positif dari seorang remaja. Sehingga, pembentukan self-concept yang positif adalah tujuan yang harus dicapai oleh para remaja.

Pada dasarnya, kedua konsep, baik self-esteem maupun self-compassion, samasama mampu menghasilkan emosi positif. Berbagai penelitian mengungkapkan, kedua variabel tersebut dapat menstimulasi terbentuknya kesehatan mental bagi semua individu termasuk remaja. (Kernis, 2005; Neff, Kirkpatrick, \& Rude, 2007; Neff \& Vonk, 2009; Persinger, 2012; Neff \& Pommier, 2012; Marshall, et al, 2014; Marshall, et al, 2015; Muris, Meesters, Pierik, Kock, 2015).

Meski demikian, konsep SelfCompassion sangat berbeda dengan selfEsteem. Self-Esteem mengacu pada penilaian dan evaluasi diri secara positif. Di dalam konsep ini, individu akan diukur sebarapa banyak dan atau seberapa sering kita menghargai diri sendiri secara positif. Kadar banyak atau sering tersebut didasarkan pada perbandingan dengan orang lain. Jika seorang individu ingin memiliki self-esteem yang tinggi, maka ia harus mendapatkan respon dari orang lain bahwa penilaian orang lain terhadap dirinya berada di atas rata-rata.

Seorang individu pun akan terus membandingkan dirinya dengan orang, serta berusaha untuk terus menjadi "lebih" dari orang lain. Neff (dalam Khazan, 2016) mengungkapkan bahwa usaha individu untuk selalu mendapatkan harga diri yang lebih tinggi dengan membandingkan dirinya dengan orang lain menjadi intimidasi terbesar terhadap dirinya sendiri. Harga diri hanya akan muncul ketika seseorang mengalami kesuksesan. Namun, ketika individu mengalami kegagalan, maka ada suatu tekanan dari dalam diri untuk memenuhinya, dan individu akan tertekan oleh karenanya (Neff, dalam Khazan, 2016).

Self-esteem memiliki pengaruh yang sangat besar terhadap perkembangan diri mereka (Harter, dalam Carranza, et al, 2009). Pada masa ini, penting bagi para remaja untuk mempunyai self-esteem yang adequate sehingga mereka lebih efektif dalam menjalani kehidupannya (Carranza, et al, 2009; Guindon, 2010). Akan tetapi, kebanyakan individu termasuk remaja akan berusaha untuk mengejar dan 
mempertahankan self-esteem yang tinggi. Usaha tersebut akan terus dilakukan hingga berpotensi memunculkan perilaku yang maladaptive, seperti ketidakmampuan mengontrol emosi, kurangnya rasa tanggung jawab terhadap tugas dan diri sendiri, menunjukkan agresi, dan bahkan pada tingkat tertentu akan membuatnya depresi (Harter, 1999, Pyszczynski, et al, 2004; Lucas, et al, 1996; Twenge \& Campbell, 2003; Crocker \& Park, 2004; Kernis, 2005; Swann; Lyubomirsky, Tkach, \& DiMatteo, 2006; Chang-Schenider, \& McClarty, 2007). Pemikirannya dan kemampuannya akan bersosialisasi akan menjadi sangat kaku dan sempit, kurang mampu menoleransi keadaan, serta sangat membutuhkan penerimaan sosial. Bahkan, sampai pada satu titik, seorang remaja akan mengalami kesulitan dalam mengembangkan konsep diri yang akurat / accurate self-concept (Sedikides, 1993; Taris, 2000; Jost, Glaser, Kruglanski, \& Sulloway, 2003). Hal inilah yang membuat remaja harusnya mencari alternatif untuk menemukan konsep diri yang lebih positif dibandingkan terjebak dalam ketergantungan pada self-esteem.

Seorang remaja yang sangat tergantung pada self-esteem dan terus berusaha mempertahankan derajatnya yang tinggi itu, bisa membuatnya frustasi. Ia harus selalu mendapatkan penilaian di atas rata-rata dari orang lain atas apa yang ia tampilkan jika ingin mendapatkan selfesteem (Twenge, 2006). Sayangnya, tidak selalu seorang individu mampu optimal dalam berbagai hal di saat yang bersamaan (Neff, 2011). Di sisi lain, remaja akan selalu menghadapi kesulitan dan tantangan dalam kehidupannya. Dinamika dan kebutuhan akan pemenuhan tugas perkembangannya akan selalu membuntutinya. Berbagai perasaan dan pengalaman akan dialami para remaja, seperti penolakan sosial, masalah keluarga, kegagalan pribadi, dan sebagainya (Laible, Carlo, Marcela, 2000; Nickersen \& Nagle, 2005; Santrock, 2007; Saraswatia, et al, 2015; Wankhade, 2016). Hal tersebut pun pada akhirnya mengguncang self-esteem para remaja yang bisa berakibat pada berkurangnya kesehatan mental individu seperti depresi, kecemasan yang berlebihan, ego yang tinggi, hingga kecenderungan narsistik (Neff \& Vonk, 2009; Persinger; 2012; Kamalinasab \& Mohammadkhani, 2017). Pada akhirnya, remaja yang terjebak dalam berbagai hal negatif tersebut tidak mampu menemukan self-concept yang positif, dan berdampak pada tidak terpenuhinya tugas perkembangan remaja (Erikson, 1968; Hayes, 2015; Neff, 2009; Neff, 2011; Muris, et al, 2015; ).

Perlu diperhatikan bahwa selfesteem adalah suatu variabel pembentuk konsep diri individu yang sangat sensitif (Leary, et al, 2007; Neff \& Vonk, 2009; 
Breines \& Chen, 2012; Persinger, 2012; Marshall, et al, 2014). Derajat self-esteem yang terlalu berlebihan bisa mengindikasikan bahwa seseorang memiliki kesehatan mental yang buruk (Orth, Robins \& Roberts, 2008 \& Orth, Robins, \& Meier, 2009). Seorang individu dengan tingkat self-esteem yang terlalu tinggi akan cenderung menjadi narsistik, merasa berhak mendapatkan perlakuan khusus, ataupun keluar dari realitas, dan bahkan bisa menyebabkan ketidaktepatan dalam membentuk konsep diri serta sulit untuk mengembangkan dirinya (Baumeister, Smart, \& Boden, 1996; Crocker \& Park, 2004; Neff \& Lamb, 2009). Begitu juga, ketika seseorang memiliki self-esteem yang rendah, maka sejumlah danpak negatif bisa terjadi seperti kecenderungan bunuh diri, dan kegagalan dalam membangun hubungan positif dengan lingkungan sekitar (Lewinsohn, Rohde, \& Seelye, 1994; Wichstrom, 2000; Marshall, et al, 2014; Khazan, dalam theatlantic.com, 2016). Self esteem yang rendah bisa menjadi akar masalah dari berbagai permasalahan khususnya pada remaja (Ciarrochi \& Bailey, 2008; Hayes, Strosahl \& Wilson, 2011).

Sedangkan, sebaliknya, selfcompassion tidak melakukan penilaian terhadap diri sebagai "baik" dan "buruk". Perspektif dari self-compassion bukan ditekankan pada berpikir positif belaka.
Namun, bagaimana respon seseorang menjadi lebih positif ketika suatu pemikiran negatif muncul (Marshall, et al, 2014; Marshall, et al, 2015; Neff, 2003b; Neff, 2011). Self-ccompassion tidak menghendaki seorang individu membandingkan dirinya dengan orang. Kesuksesan personal pun bukan menjadi indikator keberhasilan kesehatan mental di dalam konsep ini. SelfCompassion lebih pada bagaimana kita dan diri kita sendiri saling berhubungan, bahkan memotivasi diri sendiri untuk mencapai pertumbuhan pribadi (Neff, 2003b; \& Brach, 2003).

Ketergantungan remaja terhadap self-esteem dalam rangka pembentukan selfconcept-nya, perlu diimbangi dengan pengembangan self-compassion. Lagipula, secara teoritis, pengembangan selfcompassion lebih mudah daripada selfesteem (Baumeister, dkk, 2003; Neff \& Vonk, 2009). Individu yang tergolong selfcompassionate person mampu menerima diri mereka apa adanya terlepas dari pujian atau cemoohan orang lain. Sedangkan, selfesteem hanya akan "tumbuh" ketika individu berada dalam suatu penilaian yang baik dari orang lain, dan akan "hilang" ketika umpan balik negatif muncul dari orang lain terhadap dirinya (Neff, 2011).

Remaja dengan self-compassion yang tinggi akan membuatnya mampu untuk mempertahankan dan mengembangkan konsep diri yang lebih 
positif. Self-compassion menjadikan individu lebih menyayangi dirinya sendiri, lebih memperhatikannya, dan lebih mampu menerima semua keadaan yang ada. Konsep ini dinamakan sebagai aspek self-kindeness atau kebaikan kepada diri sendiri. Kebaikan akan dirinya sendiri pun membuat individu tidak mudah untuk melakukan judgement negatif terhadap dirinya. Penilaian dari orang lain terhadap diri individu menjadi sia-sia. Selain itu, remaja akan menganggap bahwa penilaian yang buruk terhadap dirinya bisa saja terjadi pada orang lain, sehingga tidak perlu dikhawatirkan. Di dalam konsep self-compassion dikenal sebagai aspek common humanity, yaitu sikap baik terhadap diri sendiri dan menganggap bahwa semua kejadian yang menimpa dirinya bisa saja menimpa orang lain sehingga tidak perlu ada yang dikhawatirkan mampu menstabilkan emosinya (Neff, 2003; Leary, et al, 2007; Neff \& Vonk, 2009; Neff, 2011; Breines \& Chen, 2012; Persinger 2012; Marshall, et al, 2014; Marshall, et al, 2015).

Di dalam self-compassion, individu tetap diajak untuk menerima keadaan dirinya dan mengevaluasi secara lebih positif. Penilaian tetap akan dilakukan oleh individu khususnya para remaja. Penilaian ini pun berasal dari persepsi individu yang subjektif ini belum tentu cocok dengan realitas yang ada. Penilaian tersebut cenderung hanya berdasar pada kemampuan dalam berbagai aspek kehidupan yang positif-negatif, antara keberhasilankegagalan, untung-malang. Namun, kegagalan tidak secara otomatis mengakibatkan harga diri yang rendah. Keberhasilan pun belum tentu meningkatkan self-esteem. Dampak dari keberhasilan maupun kegagalan sangat bergantung dari bagaimana individu memaknai dan mengartikan kondisi tersebut (Baumeister, dkk, 2003). Artinya, kesadaran penuh dari individu sebagai makhluk yang memiliki akal budi sangat diperlukan. Inilah yang dimaksud Neff (2003 \& 2011) sebagai konsep dari mindfulness.

Konsep diri dari remaja adalah bagaimana mereka mengekspresikan persepsi dan membentuknya ke dalam perilaku nyata mengenai dirinya sendiri (Ybrandt \& Armelius, 2003). Meski situasi dan orang disekitar individu berubah, selfconcept secara mendasar haruslah tetap sama. Sehingga, untuk membentuk selfconcept yang lebih baik, para remaja pada dasarnya tidak boleh terlalu terpengaruh dengan respon dari orang lain terhadap dirinya (Duffy \& Atwater, 2005). Melainkan, mereka harus mulai belajar untuk menciptakan welas asih kepada diri sendiri, sadar akan berbagai hal positif dan hal yang masih perlu dikembangkan, serta berusaha untuk memaksimalkan potensi dirinya sendiri. Para remaja pun sebaiknya 
mulai menghindari membandingbandingkan dirinya dengan orang lain. Secara sederhana, para remaja memerlukan pengembangan self-compassion daripada terjebak dalam idealisme dan standar tinggi demi pencapaian self-esteem yang lebih tinggi bagi dirinya (Persinger, 2012).

Di satu sisi, sebenarnya selfcompassion dan self-esteem sangat berpengaruh terhadap pembentukan konsep diri remaja. Kedua variabel tersebut secara signifikan mampu berpengaruh terhadap kesehatan mental individu khususnya remaja. Individu yang memiliki selfcompassion dan self-esteem yang tinggi berpotensi memiliki kesehatan mental yang baik. Sedangkan, penurunan kesehatan mental akan terjadi pada individu dengan self-compassion dan self-esteem yang rendah (Marshall, et al, 2015). Kedua variabel yang saling terkorelasi itu pun menjadi prediktor terhadap kebahagiaan, optimisme, dan perasaan positif (Neff, 2003a; Neff \& Vonk, 2009; MacBeth \& Gumley, 2012; Marshll, et all, 2015).

Akan tetapi, di sisi lain, ada sejumlah penelitian yang menjelaskan bahwa self-compassion bahkan mampu menjadi "penolong" jika seseorang mengalami permasalahan hidup yang buruk, situasi yang mengancam ego, serta permasalahan yang negatif terkait self (Breines \& Chen, 2012; Marshall, et al, 2015).Variabel ini bahkan mampu melindungi diri seseorang dari selfjudgment yang negatif, termasuk selfesteem yang rendah (Leary, Tate, Adams, Allen, \& Hancock, 2007; Neff \& Vonk, 2009; \& Kuyken, Watkins, Holden, White, Taylor, \& Byford, 2010). Self-Compassion lebih mampu memprediksi terciptanya perasaan yang stabil serta self-worth pada seorang individu dibandingkan self-esteem (Neff \& Vonk, 2009). Self-Compassion yang tinggi memampukan para remaja untuk menghadapi situasi yang berpotensi melemahkan self-esteem-nya (Neff, 2003b; Leary, Tate, Adams, Allen, \& Hancock, 2007; Gilbert, 2010; Marshall, Parker, Ciarrochi, Sahdra, Jackson \& Heaven, 2015). Self-Compassion pun membuat seorang individu mampu mengatasi berbagai tindakan maladaptive, seperti narsistik, ketidakmampuan bersosialisasi, bahkan kecenderungan bunuh diri sebagai wujud dari rendahnya self-esteem (Kernis, 2005; Neff, Kirkpatrick, \& Rude, 2007; Persinger, 2012).

Para remaja seharusnya mampu membentuk self-concept yang matang dan berkualitas. Self-esteem hanya membuat diri para remaja diliputi kebutuhan untuk merasa berada di atas orang lain atau lebih dari standart sosial yang ada. Para remaja pun terdorong untuk selalu berkompetisi, paling tidak, dengan dirinya sendiri, agar supaya "mengamankan" perasaannya bahwa ia sudah "cukup baik dan berada di 
atas rata-rata". Self-compassion difokuskan pada kualitas pribadi dimana individu akan terstimulasi agar lebih menghargai dirinya sendiri. Para remaja pun akan memperlakukan dirinya dengan lebih baik tanpa harus membandingkan diri dengan orang lain. Sikap inilah yang mampu mendorong seorang remaja untuk membentuk self-concept yang lebih positif. Secara sederhana, self-compassion mengajak individu untuk mencintai diri sendiri terlebih dahulu, sebelum ia mencintai orang lain; bentuk dan perkuat konsep diri dari dalam terlebih dahulu, sebelum lingkungan membentuk konsep dirinya.

\section{Self-compassion memberikan} kesempatan bagi para remaja untuk melihat pengalaman diri dan lingkungan sosialnya tanpa memunculkan perasaan terisolasi ataupun terpisah dari pergaulannya. Selfcompassion pun menghindarkan para remaja dari membanding-bandingkan antara dirinya dengan standar yang berlaku di masyarakat. Perasaan merasa diri paling menderita di dunia ini pun bisa terhindar dari para remaja. Kecemasan yang kerap kali menyelimuti para remaja akibat kondisi psikologis yang belum stabil bisa teratasi dengan self-compassion. Remaja mampu bangkit dari permasalahan yang ada, berusaha untuk terus melalui tantangan, dan bahkan mampu membuat mereka memaafkan kesalahan yang diperbuat olehnya. Self-compassion menjadikan diri remaja lebih damai, bahagia dan sehat dalam jangka waktu yang lama. Selfconcept yang lebih positif pun bisa dibentuk karena adanya self-compassion di dalam diri para remaja tersebut.

Tinjauan mengenai konsep teoritis Self-Compassion, dan Self-Esteem dan SelfConcept pada remaja sangat perlu dilakukan. Individu yang memasuki masa remaja sangat rentan dan membutuhkan pengembangan khususnya dari berbagai pihak. Para remaja yang berada di situasi yang tidak menentu perlu diarahkan dengan jelas, apakah ia harus mengembangkan harga diri berdasarkan perbandingan dirinya terhadap orang lain, atau konsep diri perlu dibentuk dengan mengasihani dirinya sendiri secara positif. Konsep diri yang jelas dapat membantu para remaja untuk lebih siap dan optimal dalam memasuki tahap perkembangan selanjutnya, yaitu masa dewasa (Erikson, 1968).

\section{SIMPULAN DAN SARAN}

Remaja yang sedang mencari identitasnya perlu memiliki self-esteem yang tinggi. Self-esteem akan menstimulasi remaja untuk menemukan siapa dirinya dan seperti apa dirinya kelak. Semakin tinggi self-esteem yang dimilikinya, maka semakin jelas konsep diri yang terbentuk. Sebaliknya, semakin rendah self-esteem 
dari seorang remaja, maka, semakin rendah pula konsep diri yang terbentuk.

Remaja lebih perlu berinteraksi dengan dirinya sendiri, mengasihi dirinya sendiri dan mengembangkan konsep diri yang lebih baik. Inilah yang ditawarkan oleh variabel self-compassion. SelfCompassion tetap akan "tersedia" meskipun harga diri individu jatuh. Self-Compassion akan melindungi harga diri yang terluka.

Remaja dengan self-compassion yang tinggi tetap akan menerima kritikan dan kurang terpengaruh oleh penilaian lingkungan. Kebaikan terhadap dirinya (self-kindness) akan membuat remaja lebih menerima kritikan dari lingkungan serta jarang menyalahkan dirinya sendiri. Pemikiran bahwa semua orang bisa mengalami apa yang dialaminya (common humanity) pun akan muncul. Pada akhirnya, dengan kesadaran penuh (mindfulness), ia mampu merespon segala situasi yang dialaminya dengan semestinya, tanpa dilebih-lebihkan atau dikurangi. Konsep dirinya pun akan berkembang lebih jelas dan positif.

Dengan demikian, peneliti mengusung suatu buah pikir bahwa selfcompassion lebih baik dikembangkan daripada terfokus pada self-esteem dalam rangka membantu remaja menemukan dan membentuk self-conceptnya. Secara sederhana, remaja perlu "meninggalkan" dan jangan terjebak pada self-esteem, namun, mulai mengembangkan selfcompassion. Penelitian kuantitatif dan atau kualitatif perlu dilakukan untuk membuktikan buah pikir ini benar adanya.

\section{DAFTAR Rujukan}

Augestad, L. B. (2017). Self-concept and self-esteem among children and young adults with visual impairment: A systematic review. Cogent Psychology, 4, $1-12$

Baumeister, R. F., Campbell, J.D., Krueger, J. I., \& Vohs, K. D. (2003). Does high self-esteem cause better performance, interpersonal success, happiness or healthier lifestyles?. Psychological Science in the Public Interest, 4 (1), 144

Baumeister, R. F., Smart, L., \& Boden, J. M. (1996). Relation of threatened egotism to violence and aggression: The dark side of self-esteem. Psychological Review, 1, 5-33

Brach, T. (2003). Radical acceptance: Embracing your life with the heart of a Buddha. New York, : Bantam

Breines, J. G., \& Chen, S. (2012). Selfcompassion increases selfimprovement motivation. Personality and Social Psychology Bulletin, 38(9), 1133-1143

Carranza, F.D., You, S., Chhuon, V., \& Hudley, C. (2009). Mexican american adolescent's academic achievement and aspirations: The role of perceived parental educational involvement, acculturation and self esteem. Journal Adolescence, 44 (174), 313- 334

Ciarrochi, J., \& Bailey, A. (2008). A CBTpractitioner's guide to ACT: How to bridge the gap between cognitive behavioral therapy and acceptance and 
commitment therapy. Oakland, CA: New Harbinger Publications Inc

Coopersmith, S. (1967). The antecendents of self esteem. San Fransisco: W.H. Freeman and Company

Crocker, J., \& Park, L. E. (2004). The costly pursuit of self-esteem. Psychological Bulletin, 130, 392-414

Coetzee, M. (2009). The Relationship Between Personality Preferences, Self Esteem and Emotional Competence. Diunduh dari http://uir.unisa.ac.za/dspace/handle/105 00/2045

Duffy, K. G., \& Atwater, E. (2005). Psychology for living: Adjusment, growth, and behavior today. New Jersey: Pearson Prentice Hall

Erikson, E. H. (1968). Identity, youth and crisis. New York: Norton

Gilbert, P. (2010). Compassion focused therapy: Distinctive features. London: Routledge

Guindon, M.H. (2010). Self esteem across the Lifespan. New York: Routledge Taylor \& Francis Group.

Harter, S. (1999). The construction of the self: A developmental perspective. New York: Guilford Press.

Hayes, S. C. Is self-compassion more important than self-esteem?. Diunduh dari

http://www.huffingtonpost.com/stevenc-hayes-phd/is-selfcompassion-moreim_b_6316320.html

Hayes, S. C., Strosahl, K., \& Wilson, K. G. (2011). Acceptance and commitment therapy: The process and practice of mindful change (2nd ed.). New York: The Guilford Press.
Herlina. (2013). Bibliotherapy: Mengatasi masalah anak dan remaja melalui buku. Bandung : Pustaka Cendekia utama.

Jost, J. T., Glaser, J., Kruglanski, A. W., \& Sulloway, F. J. (2003). Political conservatism as motivated social cognition. Psychological Bulletin, 129,

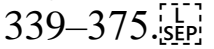

Kernis, M. (2005). Measuring self-esteem in context: The importance of stability of selfesteem in psychological functioning. Journal of Personality, 73, $1-37$.

Khazan, O. (2016). Why self-compassion better than self-esteem. Diunduh dari https://www.theatlantic.com/health/arc hive/2016/05/why-self-compassionworks-better-than-self-esteem/481473/

Kuyken, W., Watkins, E., Holden, E., White, K., Taylor, R., Byford, S., et al. (2010). How does mindfulness-based cognitive therapy work?. Behaviour Research and Therapy, 48, 1105-1112

Laible, D. J., Carlo, G. and Marcela, R. M. (2000). The differential relations of parent and peer attachment to adolescent adjustment. Journal of Youth and Adolescence, 29 (1), 45-50

Leary, M. R., Tate, E. B., Adams, C. E., Allen, A. B., \& Hancock, J. (2007). Self- compassion and reactions to unpleasant self relevant events: The implications of treating oneself kindly. Journal of Personality and Social Psychology, 92(5)

Lewinsohn, P. M., Rohde, P., \& Seeley, J. R. (1994). Psychosocial risk factors for future suicide attempts. Journal of Consulting and Clinical Psychology, 62 (2), 297-305

Lucas, R. E., Diener, E., \& Suh, E. (1996). Discriminant validity of well-being 
measures. Journal of Personality and Social Psychology, 71, 616-628

Lyubomirsky, S., Tkach, C., \& DiMatteo, M. R. (2006). What are the differences between happiness and self-esteem? Social Indicators Research, 78, 363404

Marshall, S. L., Parker, P. D., Ciarrochi, J., \& Heaven, P. C. L. (2014). Is selfesteem a cause or consequence of social support? A four year longitudinal study. Child Development, 85(3), 1275-1291

Marshall, S.L., Parker, P.D., Ciarrochi, J., Sahdra, B., Jackson, C.J. (2015). Selfcompassion protects against the negative effects of low-esteem: A longitudinal study in a large adolescent sample. Personality and Individual Differences, 74, 116-121.

Martins, M. H. V., \& Neto, V. C. (2016). Resilience and self-concept of competence in institutionalized and non-institutionalized young people. Psicologia, 30 (2), 61-76

Mruk, C.J. (2006). Self-esteem research, theory, and practice: Toward a positive psychology of self-esteem (3rd ed.). New York: Springer Publishing Company.

Muris, P., Meesters, C., Pierik, A., de Kock, B. (2015). Good for the self: Selfcompassion and other self-related constructs in relation to symptoms of anxiety and depression in non-clinical youths. Journal of Child Family Study

Neff, K. D. (2003a). The development and validation of a scale to measure selfcompassion. Self and Identity, 2, 223250

Neff, K. D. (2003b). Self-compassion: An alternative conceptualization of a healthy attitude toward oneself. Self and Identity, 2, 85-102

Neff, K. D., Kirkpatrick, K. L., \& Rude, S. (2007). Self-compassion and adaptive psychological functioning. Journal of Research in Personality, 41(1), 139154

Neff, K., \& Vonk, R. (2008). Selfcompassion versus global self-esteem: Two different ways of relating to oneself. Journal of Personality, 41, 908-916

Neff, K.，\& Lamb, L. (2009). Selfcompassion. In S. Lopez (Ed.), The encyclopedia of positive psychology. Hoboken, NJ: Wiley-Blackwell. Advance online publication,

Neff, K. (2011). Why self-compassion trumps self-esteem. Diunduh dari https://greatergood.berkeley.edu/article /item/try_selfcompassion

Neff, K. \& Pmmier, E. (2012). The relationship between self-compassion and other-focused concern among college undergraduates, community adults, and practicing mediators. Self and Identity, 1-17

Neff, K. (2017). Why we should stop chasing self-esteem and start developing self-compassion. Diunduh dari http://self-compassion.org/whywe-should-stop-chasing-self-esteemand-start-developing-self-compassion/

Nickersen, A. \& Nagle, R. J. (2005). Parent and peer attachment in late childhood and early adolescence. Journal of Early Adolescene, 25, 223 - 249

Orth, U., Robins, R. W., \& Meier, L. J. (2009). Disentangling the effects of low self- esteem and stressful events on depression: Findings from three longitudinal studies. Personality 
Processes and Individual Differences, 97(2), 307-321

Orth, U., Robins, R. W., \& Roberts, B. W. (2008). Low self-esteem prospectively predicts depression in adolescence and young adulthood. Journal of Personality and Social Psychology, 95, 695-708

Palacios, E. G., Echaniz, I. E., Fernandez, A. R., de Barron, I. C. O. (2015). Personal self-concept and satisfaction with life in adolescence, youth, and adulthood. Psichotema, 27(1), 52-58

Persinger, J. (2012). An alternative to selfesteem: Fostering self-compassion in youth. Communique’ 40(5), 20-23.

Pyszczynski, T., Greenberg, J., Solomon, S., Arndt, J., \& Schimel, J. (2004). Why do people need self-esteem?. A theoretical and empirical review. Psychological Bulletin, 130, 435-468.

Santrock, J. W. (2007). Adolescence, eleventh edition. New York: McGrawHill Companies, Inc

Sahdra, B. K., Shaver, P. R., \& Brown, K. W. (2010). A scale to measure nonattachment: A Buddhist complement to Western research on attachment and adaptive functioning. Journal of Personality Assessment, 92(2), 116-127.

Saraswatia, G.K, Zulpahiyana, Arifah, S. (2015). Faktor-faktor yang mempengaruhi konsep diri remaja di smpn 13 yogyakarta. Jurnal Ners dan Kebidanan Indonesia, 3 (1), 33-38

Swann, W. B., Chang-Schneider, C., \& McClarty, K.L (2007). Do people's self-views matter? Self-concept and self-esteem in everyday life. American Psychologist, 62, 84-94
Tafarodi, R. W., \& Swann, W. B. (1995). Self-liking and self-competence as dimensions of global self-esteem: Initial validation of a measure. Journal of Personality Assessment, 65, 322-342

Taris, T. W. (2000). Dispositional need for cognitive closure and self-enhancing beliefs. Journal of Social Psychology, $140,35-50$.

Twenge, J. M., \& Campbell, W. K. (2003). "Isn't it fun to get the respect that we're going to deserve?' Narcissism, social rejection, and aggression. Personality and Social Psychology Bulletin, 29, 261-272

Twenge, J. (2006). Generation me: Why today's young Americans are more confident, assertive, entitled-and more miserable than ever before. New York, NY: Free Press

Veiga, F \& Leite, A. (2016). Adolescents' self-concept short scale: A version of PHCSCS. Procedia: Social and behavior Sciences, 217, 631-637

Wankhade, V. R. (2015). Comparison of self-concept between rural and urbal school going adolescent. International Journal of Physical Education, Sports and Health, 3 (1), 90-93

Wichstrøm, L. (2000). Predictors of adolescent suicide attempts: A nationally representative longitudinal study of Norwegian adolescents. Journal of the American Academy of Child and Adolescent Psychiatry, 39(5), 603-610

Ybrandt, H.O, \& Armelius, B.A. (2003). Self concept in adolescence a study of age and gender differences in groups of normal and antisocial adolescents. Umea Psychology Reports, 3 